\section{Effects of Salinity Stress on the Growth, Physiology, and Yield of Soybean (Glycine $\max (\mathrm{L}$.$) Merrill)$}

\author{
Nguyen Thi Linh', Le Thi Tuyet Cham² \& Vu Ngoc Thang² \\ ${ }^{1}$ Plant Cell Biotechnology, Institute of Biotechnology, Vietnam Academic of Science and \\ Technology, Hanoi 122103, Vietnam \\ ${ }^{2}$ Faculty of Agronomy, Vietnam National University of Agriculture, Hanoi 13100, Vietnam
}

\begin{abstract}
This study was conducted to evaluate the salt tolerance ability of two soybean cultivars under salinity conditions using a selection of growth and physiological parameters. Three weeks after germination, plants began being treated with either a $100 \mathrm{mM}$ concentration of $\mathrm{NaCl}$ in Hoagland solution or a non-salinity $(0 \mathrm{mM} \mathrm{NaCl})$ solution. The results showed that the plant height, number of leaves, leaf area index, and shoot and root biomasses were significantly reduced under salt conditions. A similar tendency was observed in several physiological parameters (SPAD, Fv/Fm). Since all the salt-treated plants of the D8 cultivar were dead after 40 days under the $100 \mathrm{mM}$ $\mathrm{NaCl}$ treatment, the yield of $\mathrm{D} 8$ could not be obtained, while the treated plants of the D140 cultivar experienced a marked decrease in yield compared to the control plants. In this study, we identified that the D140 soybean cultivar had a better salt tolerance than the D8 soybean cultivar at a $100 \mathrm{mM} \mathrm{NaCl}$ concentration.
\end{abstract}

\section{Keywords}

Growth, physiology, salinity, soybean, yield

\section{Introduction}

Soybean (Glycine max (L.) Merrill) is an important crop in terms of its wide usage as an edible oil and high-protein livestock feed (Valliyodan \& Nguyen, 2008). With a high content of proteins (40$50 \%$ ), lipids (20-30\%), and carbohydrates (26-30\%), and with more than $85 \%$ of the proteins consisting of $\beta$-conglycinin and glycinin (Gibbs et al., 2004), soybean and its products play important roles in providing nutrition for both humans and animals. Moreover, soybean biodiesel is being considered as one of the alternatives to fossil fuels for the future (Hill et al., 2006). Soybean, with its relatively wide adaptability, is becoming a strategic crop in many countries around the world.

However, soybean is a salt-sensitive crop (Luo et al., 2005), as shown by high sensitivity to saline conditions. Salinity is a major
Correspondence to Ittcham@vnua.edu.vn/ vungocthang@vnua.edu.vn
Received: December 8,2020 Accepted: June 26, 2021

https://vjas.vnua.edu.vn/ 
abiotic stress limiting plant growth, photosynthesis, stomatal conductance, and crop productivity in many areas of the world (Han \& Lee, 2005). It affects almost all the growth stages of leguminous crops through osmotic and ionic stresses (El Sabagh et al., 2015a). Most of the salt stresses in nature are due to $\mathrm{Na}^{+}$salts, particularly $\mathrm{NaCl}$ (Ghassemi-Golezani et al., 2009), and the excessive accumulation of both $\mathrm{Na}^{+}$and $\mathrm{Cl}^{-}$ions from soil salinity are directly toxic to plants. A higher concentration of $\mathrm{Na}^{+}$hampers the biological role of the cytoplasm, and adversely affects other biochemical and physiological processes such as altering metabolic processes and disturbing the activity of enzymes (Hanin et al., 2016; Shu et al., 2017). The responses of crops under saline conditions are complex, and depend on the severity and duration of the salt stress and the plant developmental stage (Shannon, 1985; Neumann, 1997). The effects of salinity are observed by plant height, leaf scorch, and other growth and physiological parameters.

In Vietnam, soybean is a traditional food crop that plays a vital role in food and nutritional security with a surface of over 53,000ha and a production of over 80,000 tons (General Statistics Office of Vietnam, 2018). However, soybean production in Vietnam has been facing numerous challenges such as the decrease of arable land, disease epidemics, water scarcity, drought, and saline intrusion. Global climate change and urbanization have had adverse effects on agriculture production, especially the decline of the agricultural land area due to saline intrusion. Saline intrusion is caused by rock weathering, wind-transported materials, poorquality irrigation water, and seawater intrusion onto land (Lee et al., 2008), and negatively impacts $20 \%$ of the 310 million ha of irrigated land used for crop production (Qadir et al., 2014). Though soybean is a valuable crop, its high sensitivity to salinity is becoming a limitation to soybean production worldwide, including in Vietnam. Therefore, it is necessary to screen soybean cultivars for good quality and strong tolerance to extreme environmental conditions. To solve these problems, screening for salt tolerance has become a major goal for researchers in recent decades. In this study, we selected two soybean cultivars as the research subjects to evaluate and screen their salinity tolerance in order to determine and select the tolerant cultivar.

\section{Materials and Methods}

\section{Materials}

In this study, two soybean cultivars (D8 and D140 derived from the hybrids of AK3 and M103, and DL2 and DH4, respectively) were assessed under non-saline and saline conditions to examine their salt tolerance abilities in a net house at Vietnam National University of Agriculture during the autumn-winter season in 2018.

\section{Experimental Design}

The experiment was designed as a completely randomized design with two cultivars and two concentrations of $\mathrm{NaCl}(0$ and $100 \mathrm{mM}$ $\mathrm{NaCl}$ ). In this study, every treatment had three replicates, and each replicate included 15 plants per cultivar. Soybean seeds were sown at a $2 \mathrm{~cm}$ depth in plastic pots filled with $2.5 \mathrm{~kg}$ of sand, and placed in a covered net house.

The plastic pots $(16.5 \mathrm{~cm}$ in diameter and $13 \mathrm{~cm}$ in height) were placed in a tray $(68 \mathrm{~cm}$ in length, $43 \mathrm{~cm}$ in width, and $15 \mathrm{~cm}$ in height). The plants were irrigated with the same amount of nutrient solution once a day to ensure a stable $\mathrm{pH}$ $=6$ and electric conductivity (EC). The EC value was $1.0-1.5 \mathrm{mS} \mathrm{cm}^{-1}$ for the $0 \mathrm{mM}$ treatment and $13.1-13.4 \mathrm{mS} \mathrm{cm}^{-1}$ for the $100 \mathrm{mM}$ treatment. The basal nutrient solution used in the experiment was based on the original Hoagland's nutrient solution (Hoagland \& Arnon, 1950). The plants were exposed to salt conditions by adding $\mathrm{NaCl}$ into the nutrition solution at the concentration of $100 \mathrm{mM}$ compared with the control $(0 \mathrm{mM} \mathrm{NaCl})$ after three weeks from sprouting and the salinity treatment stopped when the soybeans started flowering.

The growth parameters of plant height $(\mathrm{cm})$, the number of leaves per plant, leaf area index (LAI) $\left(\mathrm{dm}^{2}\right.$ plant $\left.^{-1}\right)$, leaf chlorophyll content (SPAD), chlorophyll fluorescence parameter, 
and leaf scorch were recorded once a week after four weeks from the planting date (first salt treatment week). At 20 days after the initial salt treatment, the fresh and dry weights of the shoots and roots, and the length and volume of the roots were recorded.

LAI was measured with a leaf area meter (Delta-T Device Ltd., Burwell, Cambridge, UK).

SPAD was measured by a handheld chlorophyll meter (Minolta, SPAD-502, Japan). The portion for the measurement was a central part of the second uppermost leaf blade.

Chlorophyll fluorescence was measured using a portable fluorometer (Opti-Sciences Chlorophyll Fluorometer, Hudson, USA-model OS-30p). Fluorescence determinations were performed between 08:00 am and 11:00 am.

Leaf scorch is one manifestation of salt stress on plants and its degree was determined by the following formula according to Pantalone et al. (1997):

$$
\begin{aligned}
& \text { Avg. leaf scorch score } \\
& =\frac{\sum(\mathrm{LSS} i) \text { (No. of plants) }}{\text { Total no. of plants per replication }} \\
& \text { where LSS } i \text { is the level of leaf scorch. }
\end{aligned}
$$

Leaf scorch was scored from 1 to 5 , where 1 $=$ no apparent chlorosis; $2=$ slight $(25 \%$ of the leaves showed chlorosis); $3=$ moderate $(50 \%$ of the leaves showed chlorosis and some necrosis); $4=$ severe chlorosis $(75 \%$ of the leaves showed chlorosis and severe necrosis); and $5=$ dead (leaves showed severe necrosis and were withered).

The yield components and yield, including the number of flowers per plant, pods/flower ratio, the number of seeds per pod, the number of pods per plant, and 100-seed weight, were recorded at harvest time.

The salinity sensitive index was determined by the following formula:

$$
\mathrm{G}(\%)=\frac{\mathrm{M} 2-\mathrm{M} 1}{\mathrm{M} 2} \times 100 \%
$$

where $\mathrm{G}$ is the salinity sensitive index, $\mathrm{M} 1$ is the individual productivity of the salt-treated plants $\left(\mathrm{g} \mathrm{plant}^{-1}\right)$, and $\mathrm{M} 2$ is the individual productivity of the control plants $\left(\mathrm{g}_{\mathrm{g}}\right.$ plant $\left.^{-1}\right)$.

\section{Statistical Analysis}

The collected data were analyzed with an ANOVA for each variable, followed by a Tukey HSD post hoc test within cultivars or salinity levels. All statistical analyses were conducted using the statistical software IRRISTAT ver 5.0 and Microsoft Excel.

\section{Results and Discussion}

Soybean is a crop sensitive to salt stress which leads to reductions in yield (Luo et al., 2005). The main solution to overcome this obstacle is the use of salinity tolerant varieties. To find salt-tolerant genotypes, Vietnamese soybean germplasm were firstly screened with many screening criteria. The results indicated that the D140 and D8 cultivars scored the highest for salt tolerance and sensitivity, respectively. Saline soils are often complex, and there is a need for a simple method to screen soybean germplasm for salt tolerant soybean breeding under controlled conditions. This study was conducted with the selected varieties to develop a simple method which is easy, is less costly, consumes less time, and is reliable to screen soybean genotypes for salt tolerance.

\section{Effects of salinity on the plant height of soybean}

Salinity has been shown to suppress the plant height of soybean cultivars (Tunçturk et al., 2008) because of changes in plant-water relationships under salt conditions, which decrease water activity in the cell (Julkowska \& Testerink, 2015) and decrease physiological and biochemical functions of the cell (Greenway \& Munns, 1980). Figure 1 shows the effects of salt concentration on the plant height of the two soybean cultivars (D8 and D140). Fifty days after the initial watering with the salt solution, the salt treatment decreased the plant height of the D8 cultivar from $41.6 \mathrm{~cm}$ (the control) to $26.0 \mathrm{~cm}$ (100 mM NaCl salt treatment). The plant heights of the D140 cultivar were $51.0 \mathrm{~cm}$ and $34.1 \mathrm{~cm}$ in the control and salt treatment, respectively. The percentage reduction of the plant height compared to the controls was greater in the D8 cultivar $(37.5 \%)$ than in the D140 cultivar $(33.1 \%)$. 

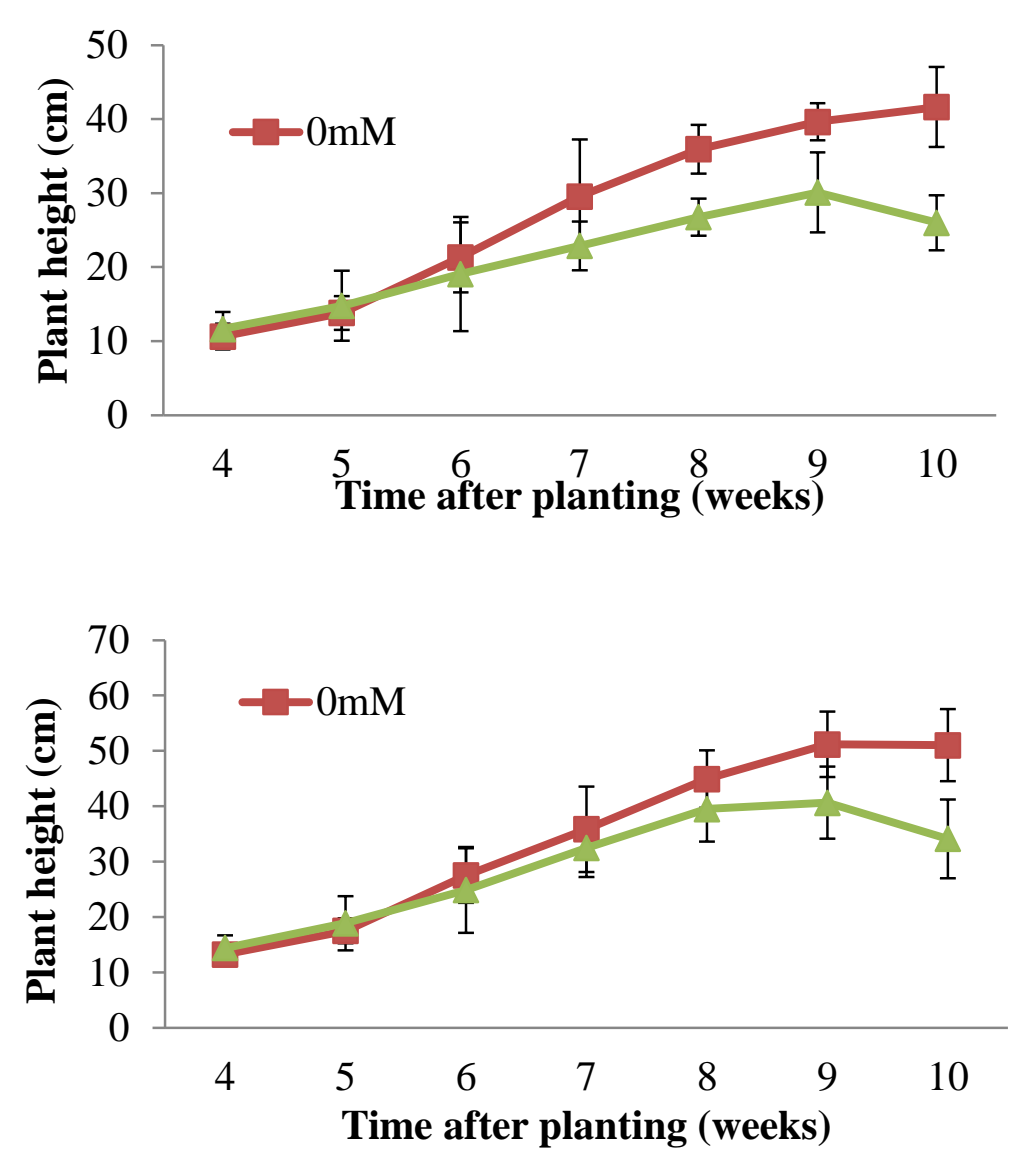

Figure 1. Effects of salinity on the plant height of the D8 cultivar (A) and D140 cultivar (B) at different growth stages (Each point in the graph represents the mean value $\pm S D, n=15), 0 \mathrm{mM}$ : control, $100 \mathrm{mM}: 100 \mathrm{mM} \mathrm{NaCl}$ treatment. An asterisk $\left({ }^{*}\right)$ indicates a significant difference between the $\mathrm{NaCl}$ treated plant height and control $(P<0.05))$.

This result showed that salt conditions caused a considerable decline in the plant heights of both cultivars, of which D8 was more affected than D140.

\section{Effects of salinity on the number of soybean leaves}

The number of leaves on a plant has been shown to be significantly affected by saline stress (El Sabagh et al., 2015b). There was a considerable difference in the number of leaves between the $\mathrm{NaCl}$ treatments in comparison with the controls (Figure 2). The number of leaves on the control plants increased steadily and reached a peak at the flowering stage, while the number of leaves on the saline-treated plants drastically decreased after 30 days of salt stress. After 50 days of the salinity treatment, the reduction from 8.6 leaves plant ${ }^{-1}$ (the control) to 3.0 leaves plant ${ }^{-1}$ $(100 \mathrm{mM} \mathrm{NaCl})$ was found in the D8 soybean cultivar while the leaves per plant in the D140 cultivar were 9.9 leaves plant ${ }^{-1}$ and 6.7 leaves plant $^{-1}$, respectively (a decline by 3.2 leaves plant $^{-1}$ ). Furthermore, it has been shown that salttolerant genotypes have lower leaf chloride contents than sensitive genotypes (Lee et al., 2008). The occurrence of leaf scorch, a symptom of $\mathrm{Cl}$ toxicity in sensitive lines, has also been shown to be higher than that of tolerant lines (Yang \& Blanchar, 1993). These observations led to the conclusion that the leaves of the saltstressed plants showed chlorosis due to the increasing salt accumulation. We concluded that increasing the salinity levels generally suppressed leaf growth and saline tolerance, and the D140 soybean cultivar was better than the D8 soybean cultivar at a $100 \mathrm{mM} \mathrm{NaCl}$ concentration in this experiment. Between them, the cultivar D140 had a higher plant height and leaf number than those parameters in the cultivar D8. 
Effects of salinity on the leaf area, and the fresh and dry weights of soybean shoots

The influence of salt stress on the leaf area, biomass, and dry matter of shoots was significant (Table 1). The $100 \mathrm{mM} \mathrm{NaCl}$ treatment showed a rapid reduction of these values in both cultivars. The leaf area of the D8 soybean cultivar fell from $6.9 \mathrm{dm}^{2}$ in the control plants to $2.24 \mathrm{dm}^{2}$ in the $\mathrm{NaCl}$ treated plants (a decrease of $67.5 \%$ ), while this index of the D140 soybean cultivar was reduced as much as $53.5 \%$ compared with the control. Salt stress directly impacts the plant biomass production of a crop (El Sabagh et al., 2015b). The fresh weight and dry matter of both the D8 and D140 soybean cultivars decreased under saline conditions (Table 1). With the increasing salt concentration levels from $0 \mathrm{mM}$ to $100 \mathrm{mM} \mathrm{NaCl}$, there was a drop by $71.7 \%$ in the plant's fresh weight of the D8 soybean cultivar, whereas the figures for the D140 cultivar declined from 15.66g to $6.98 \mathrm{~g}$ (a decrease of $55.4 \%$ ). The dry matter of the shoots in both soybean cultivars changed similarly to that of the fresh weight. A shoot dry matter reduction of $70.2 \%$ and $63.7 \%$ was found in the D8 and D140 soybean cultivars, respectively. A comparison of the responses of the different cultivars indicated that the D8 soybean cultivar was found to be damaged more than the D140 soybean cultivar. The plant height increased in parallel with the increases in root and shoot biomasses and dry weights, and root length and volume under the control conditions. Cultivar D140 had a larger increase in the growth of shoots and roots than the cultivar D8 under both conditions.

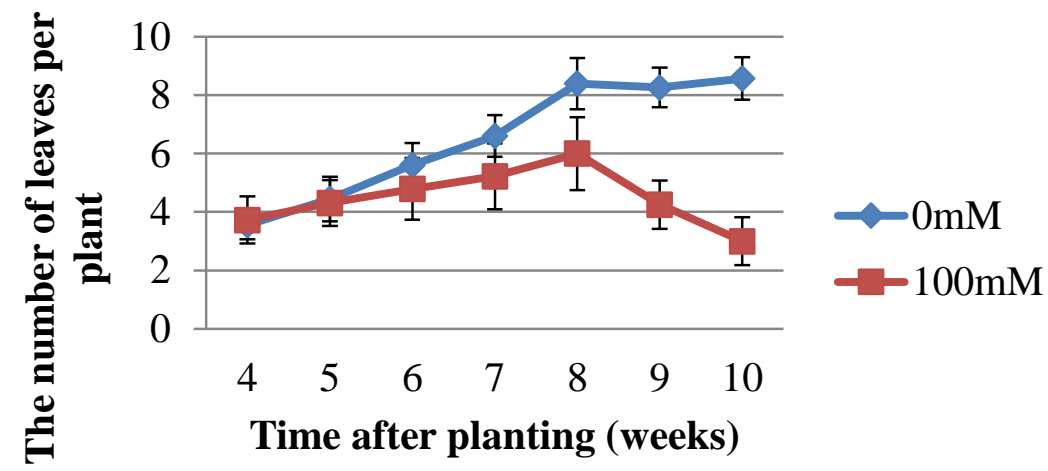

B

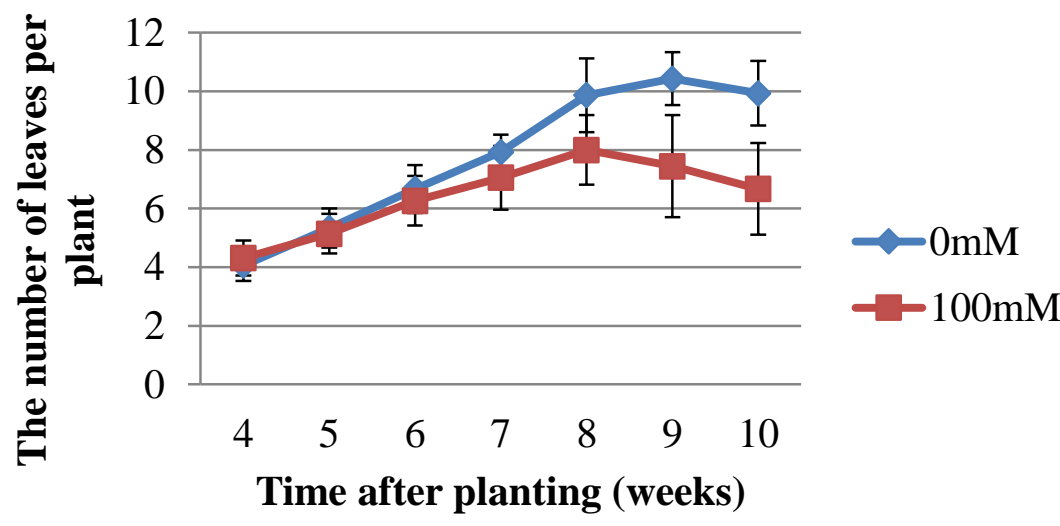

Figure 2. Effects of salinity on the number of leaves of the D8 cultivar $(A)$ and D140 cultivar (B) at different growth stages (mean value $\pm S D, n=15), 0 \mathrm{mM}$ : control, $100 \mathrm{mM}$ : $100 \mathrm{mM} \mathrm{NaCl}$ treatment. Values and standard deviations were obtained from three independent replications. The data were analyzed by analysis of variance (ANOVA) followed by a Tukey HSD post hoc test within cultivars or salinity levels. Error bars represent the standard deviation. 


\section{Effects of salinity on the root growth parameters of soybean}

The root lengths in the controls were smaller than those of the treatments but the root volumes were significantly larger. After 20 days of the salt treatment, the average root length of the D8 soybean cultivar was $26 \mathrm{~cm}$ in the control plants and $27.83 \mathrm{~cm}$ in the salt-treated plants, while the root volume decreased from $4.91 \mathrm{~cm}^{3}$ to $3.2 \mathrm{~cm}^{3}$ as the salt concentration increased. Thus, in comparison with the control, the salt treatment plants had $6.6 \%$ greater root lengths but $33.4 \%$ less root volume. This tendency was also observed in the D140 soybean cultivar: the average root length of the control plants was about $19.2 \%$ greater than that of the salinetreated plants, while the $100 \mathrm{mM} \mathrm{NaCl}$ treatment showed a significant decline of about $53.6 \%$ in the root volume compared to the control treatment. The different responses between the two cultivars were statistically significant.

Plants treated with $100 \mathrm{mM} \mathrm{NaCl}$ showed a statistically significant decreasing trend in the fresh root weights and dry matter of both the D8 and D140 soybean cultivars (Table 2). When $\mathrm{NaCl}$ was applied at $100 \mathrm{mM}$, salt stress resulted in a drop of $17.6 \%$ and $33.2 \%$ of the fresh weight of roots of the D8 and D140 soybean cultivars, respectively. A similar trend was observed in the root dry matter of the two cultivars, but it was more strongly expressed in the D140 soybean cultivar $(60.6 \%$ reduction compared to the control) than in the D8 soybean cultivar $(57.3 \%$ reduction compared to the control). The results are also consistent with Cai \& Gao (2020) who indicated that the root length and fresh and dry weights were reduced after a $\mathrm{NaCl}$ treatment.

In general, the plant height tended to increase with higher root and shoot biomasses and dry weights, and root length and volume. Cultivar D140 had a higher increase in the growth of the shoots and roots than cultivar D8.

\section{Effects of salinity on the physiological parameters of soybean}

Effects of salinity on the leaf chlorophyll content of soybean

The leaf chlorophyll content is one of the indicators that reflects the photosynthetic capacity of plants (El Sabagh et al., 2015a). Decreasing the chlorophyll content index may lead to a lower photosynthetic potential, which reduces biomass and production (Naumann et al., 2008).

Table 1. Effects of salinity on the leaf area, and the fresh and dry weights of shoots after 20 days of the salt treatment

\begin{tabular}{lcccc}
\hline \multirow{2}{*}{ Variety } & Treatment & \multicolumn{3}{c}{ Shoot growth parameters } \\
\cline { 3 - 5 } & & Leaf area $\left(\mathrm{dm}^{2}\right)$ & Fresh weight of shoot $(\mathrm{g})$ & Dry weight of shoot $(\mathrm{g})$ \\
\hline \multirow{2}{*}{ D8 } & 0 (control) & $6.90^{\mathrm{a}}$ & $14.58^{\mathrm{a}}$ & $3.89^{\mathrm{b}}$ \\
& $100 \mathrm{mM} \mathrm{NaCl}$ & $2.24^{\mathrm{b}}$ & $4.13^{\mathrm{b}}$ & $1.16^{\mathrm{c}}$ \\
\multirow{2}{*}{ D140 } & 0 (control) & $7.52^{\mathrm{a}}$ & $15.66^{\mathrm{a}}$ & $5.90^{\mathrm{a}}$ \\
& $100 \mathrm{mM} \mathrm{NaCl}$ & $3.50^{\mathrm{b}}$ & $6.98^{\mathrm{b}}$ & $2.14^{\mathrm{c}}$ \\
\hline
\end{tabular}

Note: Different letters in each column indicate a significant difference at $P \leq 0.05$.

Table 2. Effects of salinity on the root growth parameters of soybean

\begin{tabular}{lccccc}
\hline Variety & Treatment & Root length $(\mathrm{cm})$ & Root volume $\left(\mathrm{cm}^{3}\right)$ & Fresh weight of roots $(\mathrm{g})$ & Dry weight of roots $(\mathrm{g})$ \\
\hline \multirow{2}{*}{ D8 } & 0 (control) & $26.00^{\mathrm{b}}$ & $4.91^{\mathrm{b}}$ & $5.40^{\mathrm{b}}$ & $0.82^{\mathrm{b}}$ \\
& $100 \mathrm{mM} \mathrm{NaCl}$ & $27.83^{\mathrm{b}}$ & $3.27^{\mathrm{c}}$ & $4.45^{\mathrm{b}}$ & $0.35^{\mathrm{d}}$ \\
\multirow{2}{*}{$\mathrm{D} 140$} & 0 (control) & $28.33^{\mathrm{b}}$ & $9.16^{\mathrm{a}}$ & $8.22^{\mathrm{a}}$ & $1.32^{\mathrm{a}}$ \\
& $100 \mathrm{mM} \mathrm{NaCl}$ & $35.00^{\mathrm{a}}$ & $4.25^{\mathrm{bc}}$ & $5.49^{\mathrm{b}}$ & $0.52^{\mathrm{c}}$ \\
\hline
\end{tabular}

Note: Different letters in each column indicate a significant difference at $P<0.05$. 
There was no significant difference between the controls and the $100 \mathrm{mM} \mathrm{NaCl}$ treatments for leaf chlorophyll content during the first three weeks of the salinity treatment. Under the nonsalinity conditions, the chlorophyll content of the two cultivars tended to increase gradually over the period shown, while this figure in the salttreated plants rose slightly in the first two weeks of the salinity treatment before decreasing sharply in the next weeks. Twenty days after the initiation of the treatment, the chlorophyll content reduction percentages were $61.2 \%$ in the D8 soybean cultivar and $2.2 \%$ in the D140 soybean cultivar. These figures were $74.6 \%$ and $40.4 \%$, respectively, after 40 days of the salt treatment. This was because the leaves turned yellow-brown to brown and eventually withered due to the increasing $\mathrm{NaCl}$ accumulation (Figure 3). A previous study indicated that higher levels of chloride accumulated in salt sensitive plants compared with tolerant genotypes (Yang \& Blanchar, 1993). In another study, a salt sensitive cultivar had significantly higher leaf scorch scores and leaf chloride content than the tolerant cultivar (Lee et al., 2008). Hence, the leaf chlorophyll content was significantly affected by the saline conditions, in which the percentage decrease of the chlorophyll content index was greater in the D8 soybean cultivar than in the D140 soybean cultivar. There was a reduction of the plant height and chlorophyll content in response to salt stress for each cultivar, and these traits decreased more sharply in the D8 cultivar compared with the D140 cultivar.

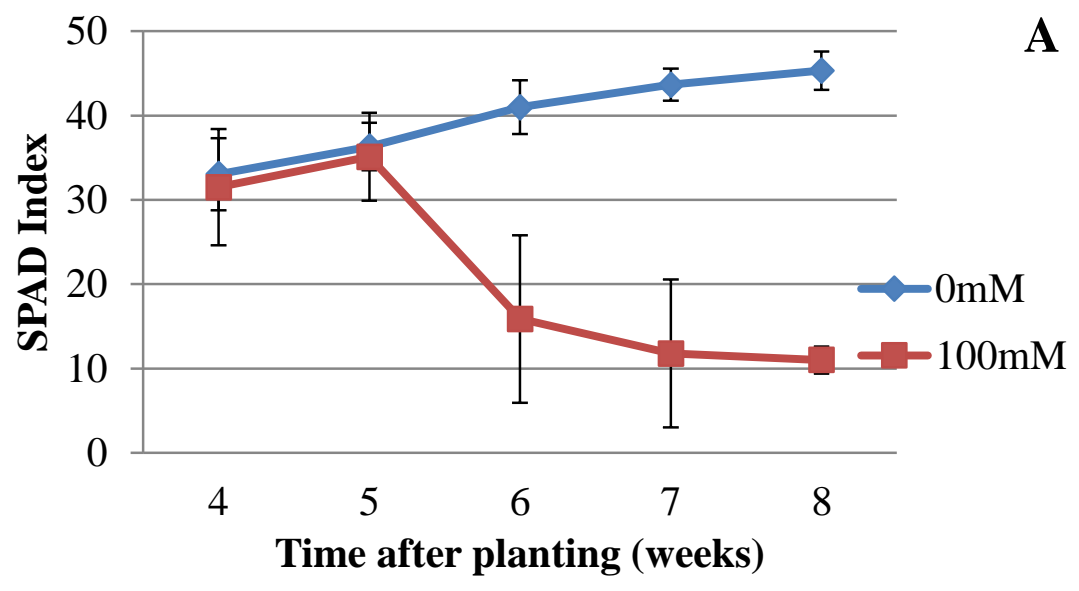

B

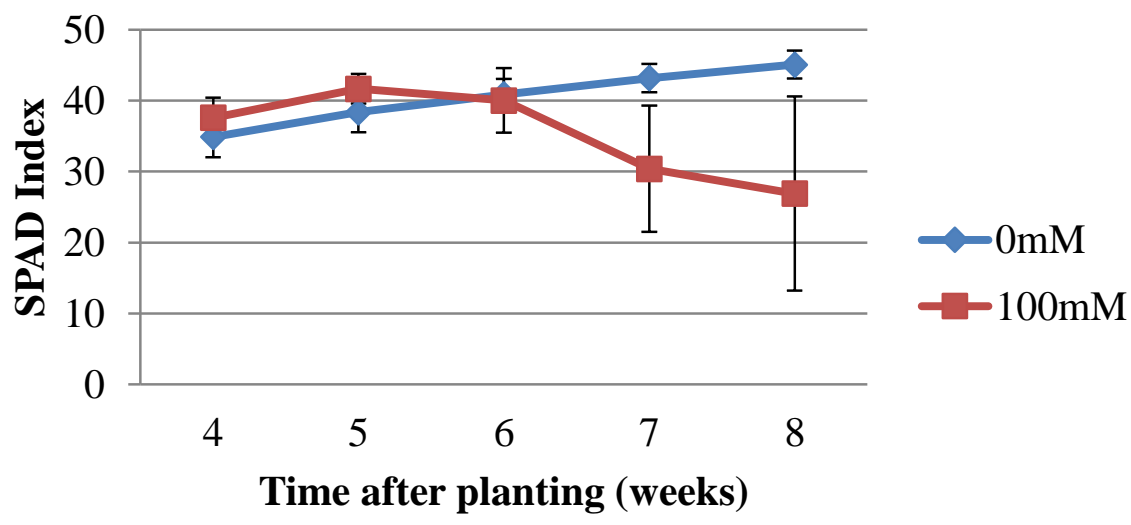

Figure 3. Effects of salinity on the leaf chlorophyll content of the D8 cultivar (A) and D140 cultivar (B) at different growth stages (mean value $\pm \mathrm{SD}, \mathrm{n}=15$ ), $0 \mathrm{mM}$ : control, $100 \mathrm{mM}: 100 \mathrm{mM} \mathrm{NaCl}$ treatment. 
Effects of salinity on the chlorophyll fluorescence parameters of soybean

The influence of salt stress on the chlorophyll fluorescence exhibited very similar patterns in the two soybean cultivars (Figure 4). Data recorded showed that the $\mathrm{Fv} / \mathrm{Fm}$ ratio, which is an indicator of the efficiency of photosystem II (Kavas et al., 2015), decreased rapidly upon treatment with $100 \mathrm{mM} \mathrm{NaCl}$. No significant change was found in the chlorophyll fluorescence in the control plants throughout the period shown, while the salinetreated plants of the two cultivars both experienced a marked decrease in the $\mathrm{Fv} / \mathrm{Fm}$. After 20 days of the $\mathrm{NaCl}$ treatment, the $\mathrm{Fv} / \mathrm{Fm}$ value reduction of the D8 soybean cultivar (31.3\%) was significant compared to the control. A similar tendency was observed in the D140 soybean cultivar with a drop of $16.2 \%$. Leaf chlorophyll fluorescence of the D8 soybean cultivar declined from 0.775 (the control) to 0.504 ( $\mathrm{NaCl}$ treatment), a decline by $35 \%$ at day 40 after initiation of the treatment. Similarly, a reduction of $32.9 \%$ in the $\mathrm{Fv} / \mathrm{Fm}$ value was found in the D140 soybean cultivar at this same time point. We concluded that the chlorophyll

A

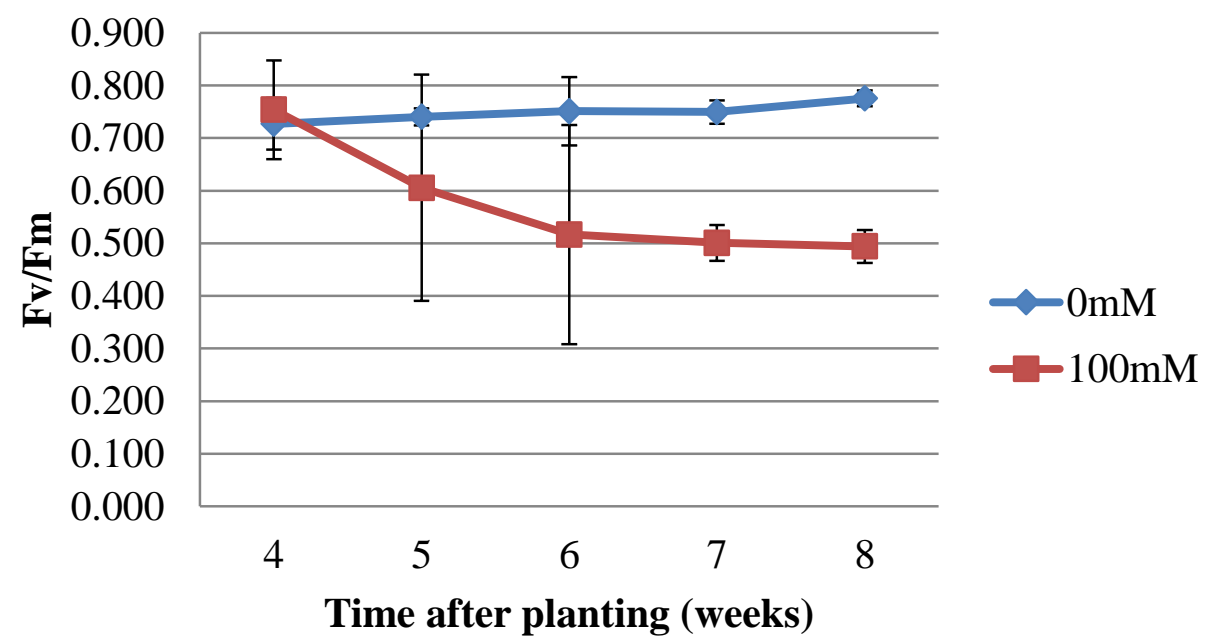

B

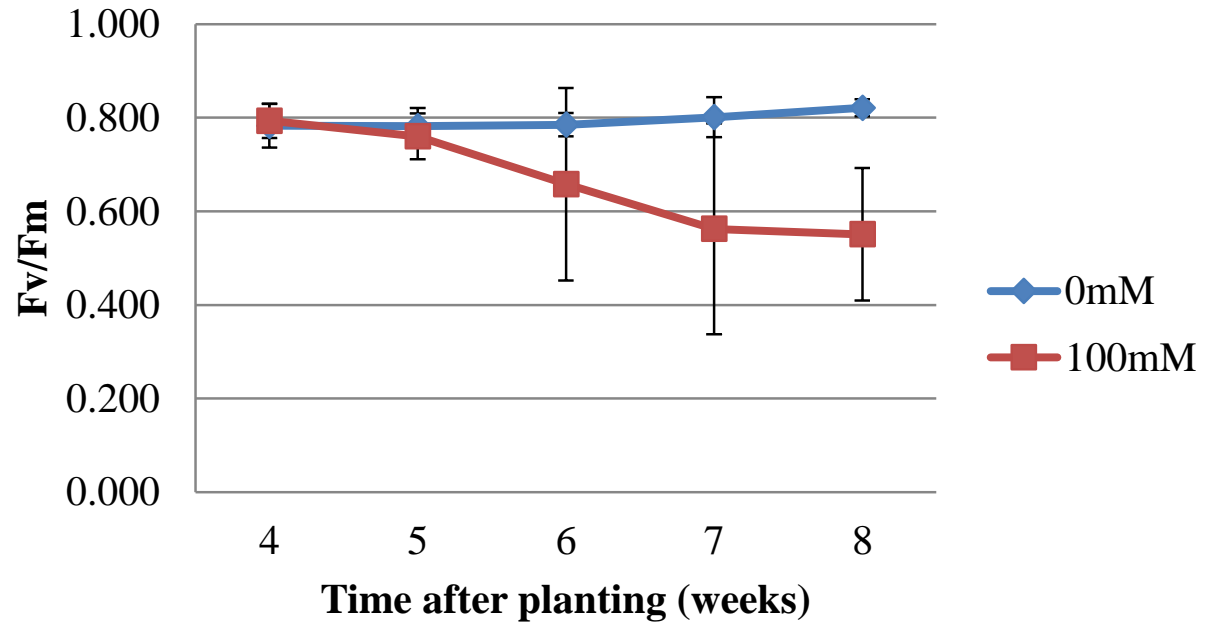

Figure 4. Effects of salinity on the chlorophyll fluorescence parameters of the D8 cultivar (A) and D140 cultivar (B) at different growth stages (mean value $\pm S D, n=15$ ), $0 \mathrm{mM}$ : control, $100 \mathrm{mM}$ : $100 \mathrm{mM} \mathrm{NaCl}$ treatmen 
fluorescence of the two cultivars in this study was depressed when salinity was increased to $100 \mathrm{mM} \mathrm{NaCl}$, in which a significant difference between the controls and the treatments was recorded in the third week of the salinity treatment.

Effects of salinity on the chlorophyll fluorescence parameters of soybean

In addition to the above parameters, leaf symptoms are also distinguishable features between high salinity-affected plants and control plants. Most plants are glycophytes, thus they are unable to restrict toxic salt ions from being translocated from the roots into the shoots and leaves (Bado et al., 2016). Consequently, salinity damage may be easily observed by symptoms on leaves like chlorosis, necrosis, leaf tip death, and leaf rolling. In this study, most of the salt-treated plants in both cultivars showed various levels of chlorosis and necrosis on their leaves with the first appearance at the tip, which then slowly spread to other parts of the leaf, while leaves of the control plants showed no injury. The leaf scorch was scored from 1 to 5 and this score was used as a parameter for the determination of salt tolerance between the soybean cultivars. Data presented in Figure 5 show that the leaf scorch of both the D8 and D140 soybean cultivars increased gradually over time after exposure to salt, but a stronger expression was observed on the D8 soybean cultivar. After four weeks under the $100 \mathrm{mM} \mathrm{NaCl}$ treatment, the leaf scorch score of the D8 soybean cultivar was 3.8 compared to 1.4 of the D140 soybean cultivar. At this time, the degree of leaf damage of the D8 soybean cultivar was nearly severe chlorosis with $75 \%$ of the leaves showing chlorosis and severe necrosis, while there were only several leaves per plant of the D140 soybean cultivar showing injury. The D8 soybean cultivar reached a leaf scorch score of 5 since all the leaves showed severe necrosis and were withered, while this figure was 4 (severe chlorosis) for the D140 cultivar after eight weeks of exposure to $100 \mathrm{mM} \mathrm{NaCl}$. We concluded that the leaves of both soybean cultivars in this experiment were affected significantly by salinity and the influence level rose over time. During which, more severe initial symptoms and a stronger expression of leaf scorch were observed on the D8 soybean cultivar.

In many previous studies, the leaf scorch score has been shown to be a reliable criterion for screening salt tolerance in soybean and to determine the appropriate $\mathrm{NaCl}$ concentrations for screening. Ledesma et al. (2016) used a leaf scorch scale to rate plants visually in order to evaluate and classify tolerant and sensitive genotypes, in which leaves were scored from 1 to 9 where 1 = healthy dark green leaves with no

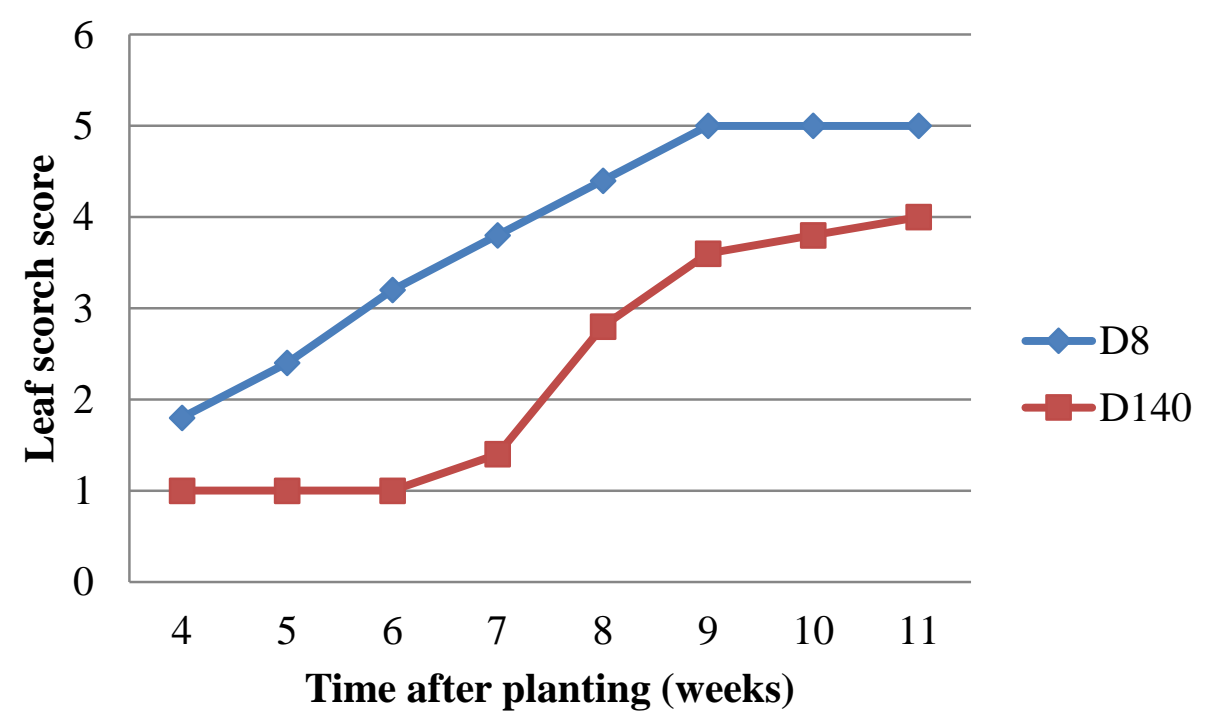

Figure 5. Effects of salinity on the leaf scorch of soybean 
chlorosis and $9=$ necrotic leaves. Based on visual leaf scorch scores, Huang et al. (2018) screened a total of 192 diverse soybean lines and cultivars at a $120 \mathrm{mM} \mathrm{NaCl}$ concentration. These results showed the potential of this criterion to be used as the main characteristic to screen salt-tolerant genotypes of soybeans in the future.

Effects of salinity on the yield componens, yield, and salinity sensitive index of soybean

The saline tolerance of the soybean cultivars in this study was assessed in terms of the yield compared to the controls. The yield and yield components are obvious parameters in evaluating salt tolerance (Richards et al., 1987). After 45 days of the salinity treatment, a significant difference was observed between the controls and the salt-treated plants (Figure 6).

The total number of flowers per plant: In the $100 \mathrm{mM} \mathrm{NaCl}$ treatment, the total number of flowers per plant showed a marked decrease in both cultivars (Table 3), and this may have been due to the inhibition of flower and pod formation under an increasing $\mathrm{NaCl}$ concentration. Salttreated plants of the D8 soybean cultivar had 11 flowers plant ${ }^{-1}$ compared to 47.4 flowers $_{\text {plant }}{ }^{-1}$ of the controls, a decrease of $76.8 \%$. The D140 soybean cultivar experienced a similar tendency with the number of flowers falling by $68.2 \%$ between the treatment and the control.

Pods/flower ratio: These grain yield data of D8 soybean cultivar could not be obtained because all the D8 salt-treated plants were dead at the time of harvest (Figure 7). The pods/flower ratio in the D140 soybean cultivar treatment plants was $22.4 \%$, much lower than that of the control plants $(63.1 \%)$.

Number of seeds/pod: This is one of the important parameters in yield formation, in which the one-seeded pods ratio is inversely correlated with the grain yield, and the threeseeded pods ratio is positively correlated with productivity. The saline-treated plants had a higher rate of one-seeded pods and a lower rate of three-seeded pod plants than the control plants.

In the D140 soybean cultivar, the percentage of one-seeded pods increased from $17.1 \%$ (the control) to $28.1 \%(100 \mathrm{mM} \mathrm{NaCl}$ treatment), while the three-seeded ratio dropped by $9.9 \%$, from $13.8 \%$ in the control plants to $3.9 \%$ in the salt-treated plants.

Table 3. Effects of salinity on the number of flowers per plant, pods/flower ratio, and the number of seeds per pod of soybean

\begin{tabular}{lccccc}
\hline Variety & Treatment & $\begin{array}{c}\text { Number of flowers } \\
\text { per plant } \\
\text { (flower) }\end{array}$ & $\begin{array}{c}\text { Pods/flower ratio } \\
(\%)\end{array}$ & $\begin{array}{c}\text { One-seeded pods } \\
\text { ratio (\%) }\end{array}$ & $\begin{array}{c}\text { Three-seeded pods } \\
\text { ratio (\%) }\end{array}$ \\
\hline D8 & 0 (control) & $47.4^{\mathrm{a}}$ & 55.1 & 19.7 & 18.2 \\
\hline \multirow{2}{*}{ D140 } & $100 \mathrm{mM} \mathrm{NaCl}$ & $11.0^{\mathrm{b}}$ & - & - & $13.8^{\mathrm{a}}$ \\
\hline
\end{tabular}

Note: Data cannot be obtained (-) Different letters in each column indicate a significant difference at $P<0.05$.

Table 4. Effects of salinity on the number of pods/plant, 100-seed weight, and individual grain yield of soybean

\begin{tabular}{|c|c|c|c|c|c|}
\hline Variety & Treatment & $\begin{array}{l}\text { Number of pods } \\
\text { per plant (pods) }\end{array}$ & $\begin{array}{l}100 \text {-seed } \\
\text { weight }(\mathrm{g})\end{array}$ & $\begin{array}{l}\text { Individual grain yield } \\
\text { (g/plant) }\end{array}$ & $\begin{array}{c}\text { \% reduction of individual } \\
\text { grain yield compared to } \\
\text { the control }(\%)\end{array}$ \\
\hline \multirow{2}{*}{ D8 } & 0 (control) & 26.1 & 19.2 & 9.1 & \multirow[b]{2}{*}{-} \\
\hline & $100 \mathrm{mM} \mathrm{NaCl}$ & - & - & - & \\
\hline \multirow{2}{*}{ D140 } & 0 (control) & $36.3^{a}$ & $15.8^{a}$ & $8.7^{a}$ & \\
\hline & $100 \mathrm{mM} \mathrm{NaCl}$ & $4.1^{b}$ & $12.5^{\mathrm{a}}$ & $0.9^{b}$ & 89.2 \\
\hline
\end{tabular}

Note: Data cannot be obtained (-). Different letters in each column indicate a significant difference at $P<0.05$. 
The number of pods per plant: Under salt stress, the number of pods per plant decreased dramatically compared to the non-salinity conditions (Table 4). The D140 salt-treated plants

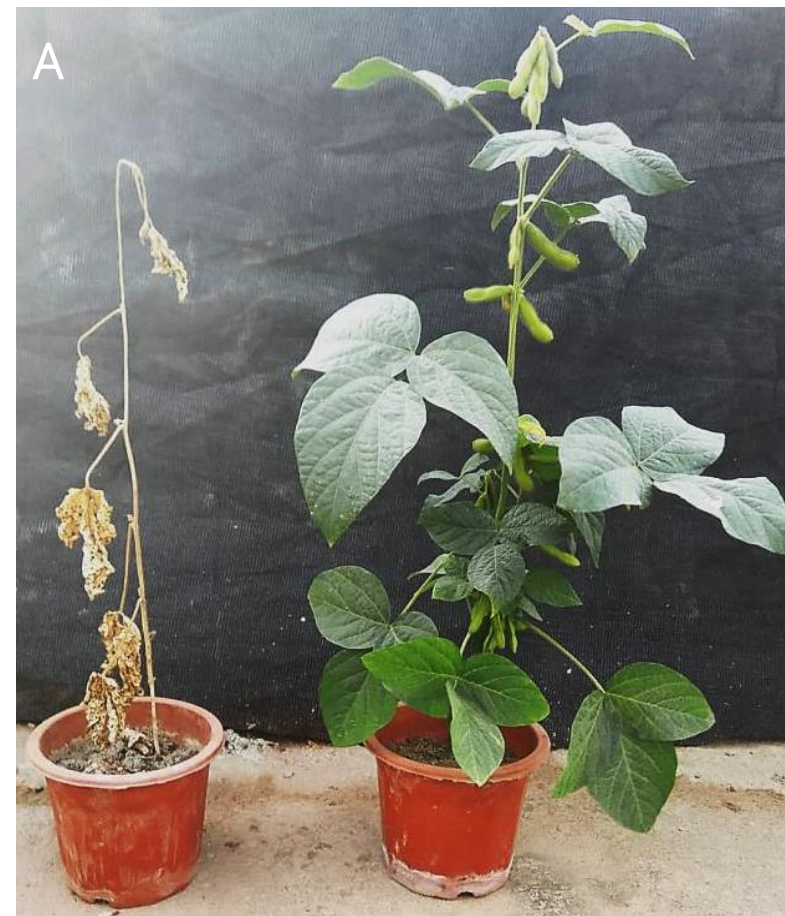

$100 \mathrm{mM} \mathrm{NaCl}$

Control had 4.1 pods plant ${ }^{-1}$ compared to 36.3 pods plant $^{-1}$ of the control plants, a decrease of $88.7 \%$.

100-seed weight: In the D140 soybean cultivar, the 100-seed weights of the treatment

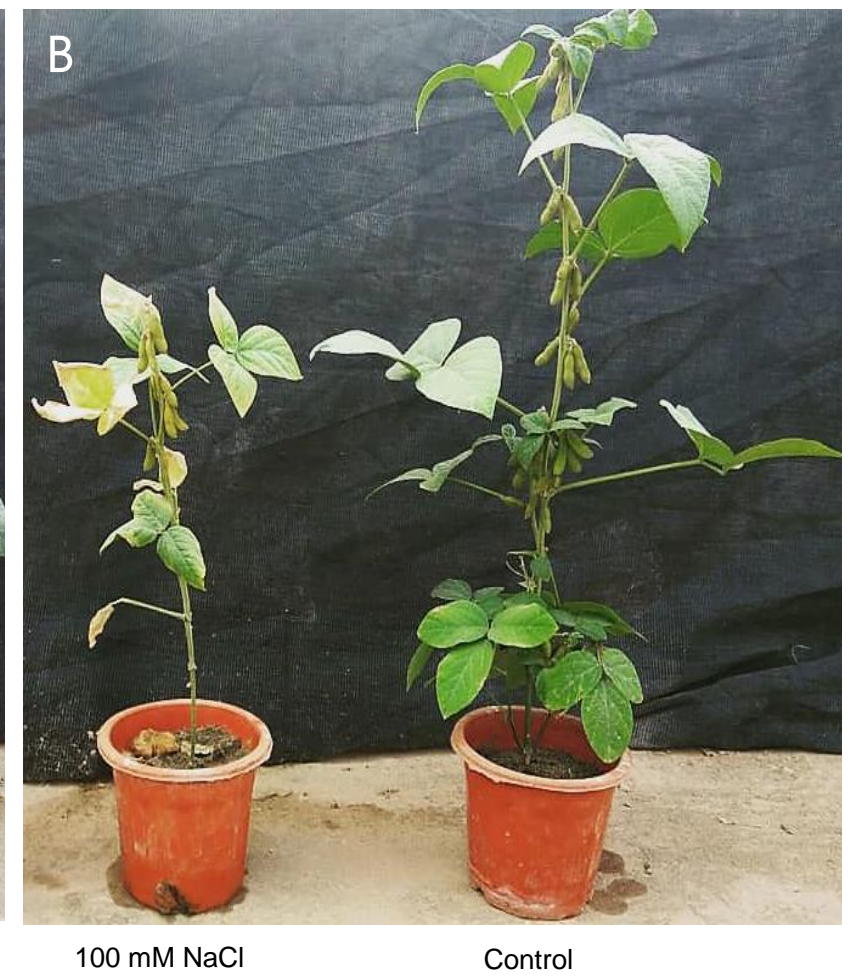

Figure 6. D8 cultivar (A) and D140 cultivar (B) after 45 days of the salt treatment

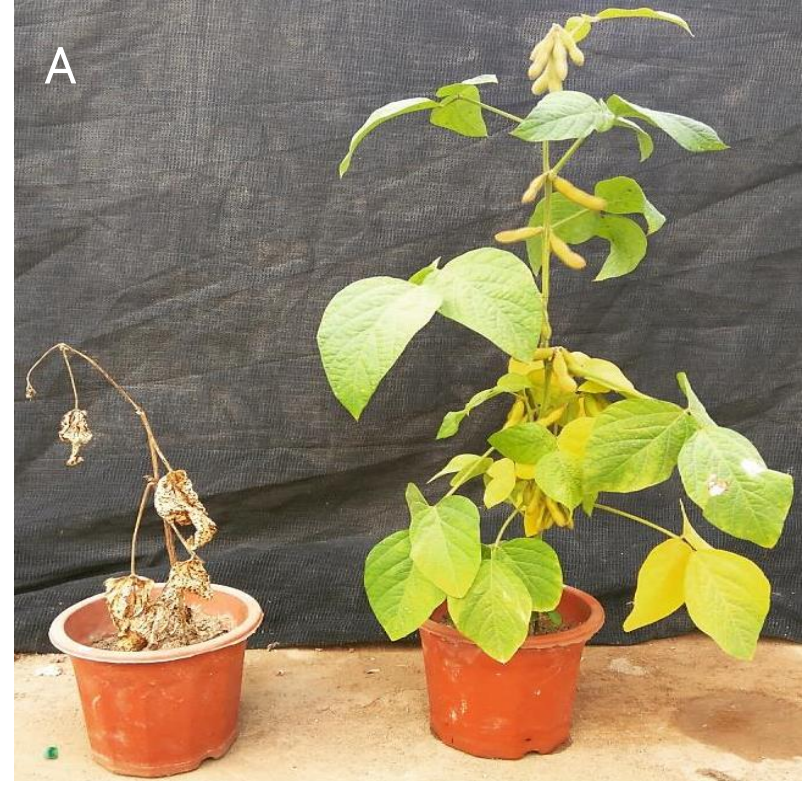

$100 \mathrm{mM} \mathrm{NaCl}$

Control

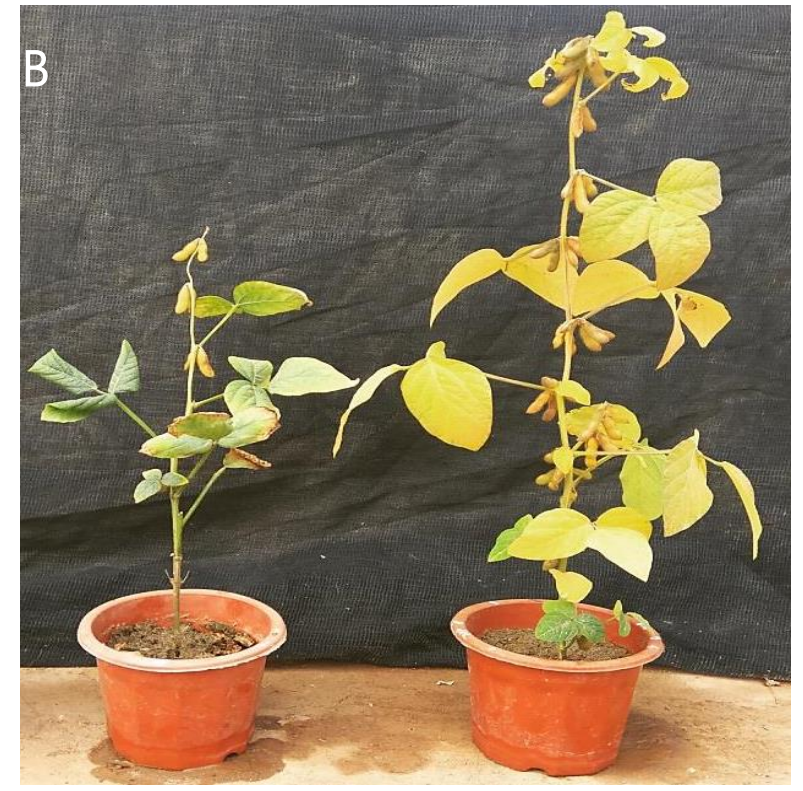

$100 \mathrm{mM} \mathrm{NaCl}$

Control

Figure 7. D8 cultivar (A) and D140 cultivar (B) at the period of pod ripening and seed maturation 
and control were $12.5 \mathrm{~g}$ and $15.8 \mathrm{~g}$, respectively, a decrease of $10.9 \%$.

Individual productivity: Data presented in Table 4 show a marked decrease in terms of individual productivity between the saline and non-saline treated plants. The productivity for the D8 treatment plants could not be obtained while the figure for the control plants was $9.1 \mathrm{~g}$. There was a drop from $8.7 \mathrm{~g} / \mathrm{plant}$ of the non-salttreated plants to $0.9 \mathrm{~g} \mathrm{plant}^{-1}$ of the $100 \mathrm{mM}$ salttreated plants.

In a previous study, the decreases in grain yield and the yield components were believed to be the result of declines in parameters such as dry matter weight, plant height, and the total number of leaves per plant caused by saline conditions (Jain \& Singh, 1989). In this study, we obtained similar results when screening two soybean cultivars (D8 and D140) using 0 and $100 \mathrm{mM}$ $\mathrm{NaCl}$ treatments.

\section{Conclusions}

Increasing the level of salinity generally suppressed the plant growth of both soybean cultivars. Growth parameters such as plant height, number of leaves/plant, LAI, the fresh weights and dry matter of shoots and roots, and the root length and volume decreased dramatically under salt conditions. Additionally, the $100 \mathrm{mM} \mathrm{NaCl}$ concentration had significant effects on the physiological parameters of the two soybean cultivars such as the leaf chlorophyll content (SPAD), the chlorophyll fluorescence, and the leaf scorch. Our data demonstrated that salinity conditions reduced the grain yield and yield components of the D140 cultivar, while these figures of the D8 soybean cultivar could not be obtained due to the death of the salt-treated plants about 40 days after the initial salt treatment. Based on our attained data, the D140 soybean cultivar could be considered more tolerant to salinity than the D8 soybean cultivar.

\section{Acknowledgments}

We would like to thank the Department of Plant Genetics and Breeding, Faculty of
Agronomy, Vietnam National University of Agriculture for their technical assistance in this research.

\section{References}

Bado S., Forster B. P., Ghanim A., Jankowicz-Cieslak J., Berthold G. \& Luxiang L. (2016). Protocols for prefield screening of mutants for salt tolerance in rice, wheat and barley. Springer Nature: 3-4.

Cai. Z. Q. \& Gao Q. (2020). Comparative physiological and biochemical mechanisms of salt tolerance in five contrasting highland quinoa cultivars. BMC Plant Biology. 20: 70.

El Sabagh A., Abd O., Saneoka H. \& Barutçular C. (2015a). Comparative physiological study of soybean (Glycine $\max$ L.) cultivars under salt stress. Yüzüncü Y1l Üniversitesi Tarım Bilimleri Dergisi. 25(3): 269-284.

El Sabagh A., Omar A., Saneoka H. \& Barutçular C. (2015b). Physiological performance of soybean germination and seedling growth under salinity stress. Dicle University Institute of Natural Applied Science Journal. 4(1): 6-15.

General Statistics Office of Vietnam (2018). Agriculture, Forestry and Fishery 2018. Retrieved from https://www.gso.gov.vn/en/agriculture-forestry-andfishery/ on May 25, 2021.

Ghassemi-Golezani K., Taifeh-Noori M., Oustan S. \& Moghaddam M. (2009). Response of soybean cultivars to salinity stress. Journal of Food, Agriculture and Environment. 7 (2): 401-404.

Gibbs B. F., Zougman A., Masse R. \& Mulligan C. (2004). Production and characterization of bioactive peptides from soy hydrolysate and soy-fermented food. Food Research International. 37(2): 123-131.

Greenway H. \& Munns R. (1980). Mechanisms of salt tolerance in nonhalophytes. Annual review of plant physiology. 31(1): 149-190.

Han H. S. \& Lee K. D. (2005). Physiological responses of soybean-inoculation of Bradyrhizobium japonicum with PGPR in saline soil conditions. Research Journal of Agriculture and Biological Sciences. 1(3): 216-221.

Hanin M., Ebel C., Ngom M., Laplaze L. \& Masmoudi K. (2016). New insights on plant salt tolerance mechanisms and their potential use for breeding. Frontiers in plant science. 7: 1787.

Hill J., Nelson E., Tilman D., Polasky S. \& Tiffany D. (2006). Environmental, economic, and energetic costs and benefits of biodiesel and ethanol biofuels. Proceedings of the National Academy of Sciences. 103(30): 11206-11210.

Hoagland D. R. \& Arnon D. I. (1950). The waterculture method for growing plants without soil. Circular ( $2^{\text {nd }}$ ed.). California Agricultural Experiment Station: 347.

Vietnam Journal of Agricultural Sciences 
Huang L., Zeng A., Chen P., Wu C., Wang D. \& Wen Z. (2018). Genomewide association analysis of salt tolerance in soybean [Glycine $\max (\mathrm{L}$.) Merr.]. Plant Breeding. 137(5): 714-720.

Jain R. \& Singh M. (1989). Factors affecting goatweed (Scoparia dulcis) seed germination. Weed Science: 766-770.

Julkowska M. M. \& Testerink C. (2015). Tuning plant signaling and growth to survive salt. Trends in Plant Science. 20(9): 586-594.

Kavas M., Akça O. E., Akçay U. C., Peksel B., Eroğlu S., Öktem H. A. \& Yücel M. (2015). Antioxidant responses of peanut (Arachis hypogaea L.) seedlings to prolonged salt-induced stress. Archives of Biological Sciences. 67(4): 1303-1312.

Ledesma F., Lopez C., Ortiz D., Chen P., Korth K. L., Ishibashi T., Zeng A., Orazaly M. \& Florez-Palacios L. (2016). A Simple Greenhouse Method for Screening Salt Tolerance in Soybean. Crop Science. 56(2): 585-594.

Lee J. D., Smothers S. L., Dunn D., Villagarcia M., Shumway C. R., Carter Jr T. E. \& Shannon J. G. (2008). Evaluation of a simple method to screen soybean genotypes for salt tolerance. Crop Science. 48(6): 2194-2200.

Luo Q., Yu B. \& Liu Y. (2005). Differential sensitivity to chloride and sodium ions in seedlings of Glycine max and $G$. soja under $\mathrm{NaCl}$ stress. Journal of plant physiology. 162(9): 1003-1012.

Naumann J. C., Young D. R. \& Anderson J. E. (2008). Leaf chlorophyll fluorescence, reflectance, and physiological response to freshwater and saltwater flooding in the evergreen shrub, Myrica cerifera. Environmental and Experimental Botany. 63(1): 402-409.

Neumann P. (1997). Salinity resistance and plant growth revisited. Plant, Cell \& Environment. 20(9): 1193-1198.

Pantalone V. R., Kenworthy W. J., Slaughter L. H. \& James B. R. (1997). Chloride tolerance in soybean and perennial Glycine accessions. Euphytica. 97(2): 235239.

Richards R. A., Dennett C. W., Qualset C. O., Epstein E., Norlyn J. D. \& Winslow M. D. (1987). Variation in yield of grain and biomass in wheat, barley, and triticale in a salt-affected field. Field Crops Research. 15(3-4): 277-287.

Shannon M. C. (1985). Principles and strategies in breeding for higher salt tolerance. In: Biosalinity in Action: Bioproduction with Saline Water. Springer, 227-241.

Shu K., Qi Y., Chen F., Meng Y., Luo X., Shuai H., Zhou W., Ding J., Du J. \& Liu J. (2017). Salt stress represses soybean seed germination by negatively regulating GA biosynthesis while positively mediating ABA biosynthesis. Frontiers in plant science. 8: 1372.

Tunçturk M., Tunçturk R. \& Yasar F. (2008). Changes in micronutrients, dry weight and plant growth of soybean (Glycine max L. Merrill) cultivars under salt stress. African Journal of Biotechnology. 7(11): 16501654.

Valliyodan B. \& Nguyen H. T. (2008). Genomics of abiotic stress in soybean. Springer, New York, NY: 343-372.

Yang J. \& Blanchar R. W. (1993). Differentiating chloride susceptibility in soybean cultivars. Agronomy Journal. 85(4): 880-885. 